\title{
Pengaruh Tingkat Naungan dan Takaran Pupuk Kandang Kambing Etawa terhadap Pertumbuhan dan Hasil Kedelai (Glycine max (L.) Merrill) di Lahan Pasir Pantai
}

\author{
The Effect of Shade Levels and Etawa Goat Manure Dosage on The Growth \\ and Yield of Soybean (Glycine max (L.) Merrill) at Coastal Sandy Areas
}

\author{
Suhesti Mustika Ningrum, Tohari, Dyah Weny Respatie ${ }^{*}$ \\ Departemen Budidaya Pertanian, Fakultas Pertanian, Universitas Gadjah Mada \\ Jalan Flora No. 1, Bulaksumur, Sleman, Yogyakarta 55281, Indonesia. \\ *) Penulis untuk korepondensi E-mail: wenyrespatie@ugm.ac.id.
}

\begin{abstract}
This study aims to determine the level of critical shade and recommendation of etawa goat manure on the growth and yield of Dena-1 cultivar soybean cultivated in Coastal Sandy Areas, Samas. In the future, the research results can be used as a benchmark for farmers to determine plant composition for intercropping systems, planting site selection, and manure dosage. This research was conducted in March up to September 2016. This research used split plot design. The main plot treatment was shading levels at $0 \%, 25 \%$, and $50 \%$ and the sub plot treatment was dosage of Etawa goat manure i.e. 0 tons. ha-1 (control), 10 tons.ha1, and 20 tons.ha-1. Data collection based on environmental parameters, physiology, and agronomy. The results showed that shade treatment was able to give significant effect on leaf 42 days after planting, dry weight of canopy, root length, dry weight of 63 days after planting, fresh weight of plant 42 and 63 days after planting, dry weight of plant 63 days after planting, empty and filled pods, and flowering date plants. Dosage of Etawa goat manure resulted significant effect on leaf area and leaf area index at 21 days after planting (DAP), number of leaves, root length, fresh weight and dry crop at 63 DAP, roots fresh weight at 21 DAP and 42 DAP, root/shoot ratio, empty and filled pods, and yield. There was interaction between treatments on chlorophyll a and total chlorophyll at 42 DAP, coefficient a and $c$ of plant height at 42 DAP, root length at 63 DAP. Critical shade levels at $59,25 \%$ was obtained by 20 ton.ha ${ }^{-1}$ of Etawa goat manure and at $58,16 \%$ was obtained by control. The best treatment combination was $25 \%$ shading level and 10 ton.ha $^{-1}$ of etawa goat manure.
\end{abstract}

Keywords: soybean, shading, goat manure, coastal sandy areas

\section{INTISARI}

Penelitian ini bertujuan untuk menentukan tingkat naungan kritis dan rekomendasi pupuk kandang kambing etawa terhadap pertumbuhan dan hasil kedelai kultivar Dena-1 yang dibudidayakan di Lahan Pasir Pantai Samas, Bantul. Tujuan jangka panjang dari penelitian ini adalah dapat memberikan informasi yang dapat digunakan sebagai tolok ukur petani dalam menentukan komposisi tanaman pada sistem tumpangsari, pemilihan lokasi tanam, dan takaran pupuk kandang 
pada tanaman kedelai. Penelitian dilaksakan pada bulan Maret-September 2016. Penelitian ini menggunakan Rancangan Petak Terbagi (split plot design). Faktor utama (main plot) adalah naungan dengan tingkat $0 \%$, 25\%, dan $50 \%$. Faktor kedua (sub plot) adalah pupuk kandang kambing Etawa takaran 0 ton/ha (kontrol), 10 ton.ha- ${ }^{-1}$, dan 20 ton.ha ${ }^{-1}$. Data yang dikumpulkan meliputi parameter lingkungan, fisiologi, dan agronomi. Hasil penelitian menunjukkan bahwa perlakuan naungan berpengaruh nyata terhadap luas daun 42 hst, bobot kering tajuk, panjang akar, bobot kering tanaman 63 hst, bobot segar tanaman 42 dan 63 hst, bobot kering tanaman 63 hst, jumlah polong hampa dan berisi, umur mulai berbunga, umur mulai terbentuk polong, dan umur panen. Takaran pupuk kandang kambing Etawa berpengaruh nyata pada luas daun dan indeks luas daun 21 hst, jumlah daun, panjang akar, bobot segar dan kering tanaman 63 hst. Bobot segar akar 21 dan 42 hst, rasio akar/tajuk, jumlah polong hampa dan berisi, dan hasil kedelai. Terdapat interaksi antar perlakuan pada kadar klorofil a dan klorofil total 42 hst, koefisien a dan c tinggi tanaman 42 hst, panjang akar 63 hst. Tingkat naungan kritis terjadi pada naungan $59,25 \%$ pada takaran pupuk kandang kambing Etawa 20 ton.ha-1 dan naungan $58,16 \%$ pada takaran pupuk 0 ton.ha-1. Kombinasi perlakuan yang paling baik adalah taraf naungan $25 \%$ dengan pupuk kandang kambing Etawa 10 ton.ha-1.

Kata kunci : kedelai, naungan, pupuk kandang kambing Etawa, lahan pasir pantai

\section{PENDAHULUAN}

Dewasa ini kebutuhan makanan pokok berupa protein nabati semakin meningkat. Sumber protein nabati yang banyak diminati oleh sebagian besar penduduk adalah kedelai. Kebutuhan kedelai semakin meningkat sejalan dengan meningkatnya jumlah penduduk serta kesadarannya terhadap protein nabati. Salah satu permasalahan utama dalam mewujudkan kemandirian pangan adalah permintaan lebih banyak dan cepat daripada penyediaannya. Permintaan meningkat cepat seiring dengan meningkatnya jumlah penduduk, peningkatan daya beli, dan perubahan selera masyarakat. Kapasitas penyediaan yang semakin berkurang disebabkan adanya konversi lahan pertanian menjadi non pertanian, penurunan produktivitas tanah, degradasi kesuburan tanah, serta tenaga kerja pertanian semakin berkurang. Salah satu upaya yang dapat dilakukan untuk mendukung peningkatan produksi kedelai yaitu melalui ekstensifikasi lahan. Lahan yang berpotensi untuk dikembangkan adalah lahan pasir pantai dan lahan di bawah tegakan pohon hutan. Lahan tersebut tergolong sebagai lahan marjinal potensial.

Uji coba penanaman kultivar kedelai toleran perlu dilakukan. Penelitian mengenai respon fisiologi dan hasil kedelai toleran naungan berbasis agroforestri dapat menjadi salah satu upaya ekstensifikasi lahan. Hasil dari penelitian ini diharapkan bisa menjadi rekomendasi bagi petani hutan rakyat dalam pengembangan kedelai. Dalam 
penelitian ini, uji coba penanaman kultivar toleran naungan dilakukan di lahan pasir pantai dengan memodifikasi lingkungan iklim mikro tanaman menggunakan naungan paranet. Naungan paranet berperan sebagai model tegakan pohon hutan.

Daerah Istimewa Yogyakarta memiliki lahan pasir pantai seluas 13.000 hektar, bentangan pasir pantai berkisar antara 1-3 km dari garis pantai. Lahan pasir terbentang sepanjang $110 \mathrm{~km}$ di pantai selatan D.I.Y (Sunghening et al., 2012). Kendala yang dihadapi dalam budidaya kedelai di lahan pasir adalah sifat fisik tanah yang tidak dapat menyimpan lebih banyak bahan organik, air, unsur hara, lengas tanah, serta iklim makro yang tergolong ekstrim. Salah satu faktor utama yang harus diperhatikan dalam budidaya tanaman adalah kesuburan tanah. Upaya untuk mengatasi beberapa faktor penghambat tersebut yakni dengan memanipulasi iklim mikro tanaman. Dalam penelitian ini, manipulasi lingkungan dilakukan dengan memasang naungan paranet, menambahkan bahan organik berupa pupuk kandang kambing Etawa.

Berdasarkan uraian diatas maka dalam penelitian ini dilakukan penanaman kedelai dengan beberapa perlakuan naungan dan takaran pupuk kandang kambing Etawa. Naungan adalah faktor yang paling penting dalam penelitian ini karena naungan berperan sebagai model tegakan hutan serta sebagai wind breaker, sedangkan pupuk kandang dengan berbagai takaran berperan sebagai bahan pembenah tanah dan peubah lengas tanah. Kandungan unsur hara dalam pupuk kandang kambing yakni 1,26\% N, 16,36 mg.kg-1 P, 2,29 mg.L-1 Ca, Mg dan 4,8\% C-organik (Rahayu et al., 2014). Kedua perlakuan tersebut sebagai penentu pertumbuhan dan hasil kedelai di lahan marjinal, seperti halnya lahan pasir pantai dan hutan. Kultivar berperan penting dalam produksi kedelai, karena untuk mencapai hasil yang tinggi sangat ditentukan oleh potensi genetik tanaman. Potensi hasil di lapangan akan dipengaruhi oleh interaksi antara faktor genetik dengan kondisi lingkungan yang ada. Potensi hasil yang tinggi dari suatu kultivar kedelai unggul tidak dapat tercapai apabila pengelolaan lingkungan tidak disesuaikan dengan syarat tumbuh tanaman tersebut (Adisarwanto, 2006). Penelitian ini bertujuan untuk dapat memberikan informasi yang dapat digunakan sebagai tolok ukur petani dalam menentukan komposisi tanaman pada sistem tumpangsari, pemilihan lokasi tanam, dan takaran pupuk kandang pada tanaman kedelai.

\section{BAHAN DAN METODE}

Penelitian dilaksanakan pada bulan Maret-September 2016 di Lahan Pasir Pantai Samas, Sanden, Bantul, Yogyakarta. Pengamatan variabel destruktif dilakukan di Laboratorium Manajemen Produksi Tanaman, Departemen Budidaya Pertanian, 
Fakultas Pertanian, Universitas Gadjah Mada, Yogyakarta. Bahan yang digunakan dalam penelitian ini adalah benih kedelai kultivar Dena 1 yang diperoleh dari BALITKABI, pupuk kandang kambing Etawa, jerami, pupuk urea, phonska, furadan, dan pestisida. Alat yang digunakan adalah paranet, bambu, paku, palu, leaf area meter (Delta-T Devices Ldt Serial No CB380495, 220 V, 50 Hz), thermo-hygrometer, mikroskop binokuler digital Olympus (Germany), optilab mikroskop digital tipe advanced, kamera, penggaris/meteran, karung, timbangan analitik, gunting/cutter, oven (ELE International A-01-285) tahun pembuatan 2005 dengan suhu maksimal $250^{\circ} \mathrm{C}$, Spektrofotometer UVVis (UV 1800. 230 VCE) tahun pembuatan 2006, alat tulis, dan alat-alat pertanian lainnya.

Penelitian disusun menggunakan Rancangan Petak Terbagi (Split-plot Design) dengan tiga ulangan. Faktor utama adalah naungan yang terdiri dari tiga taraf yakni naungan $0 \%$ (kontrol), naungan 25\%, dan naungan 50\%. Faktor kedua adalah takaran pupuk kandang kambing Etawa yang terdiri dari 3 taraf yakni 0 ton.ha-1 ${ }^{-1}, 10$ ton.ha- ${ }^{-1}$, dan 20 ton.ha-1.

Perlakuan naungan dilakukan dengan pemasangan paranet pada petak percobaan. Paranet dipasang berdasarkan kerangka bambu memanjang dari arah utara ke selatan. Lebar paranet $4 \mathrm{~m}$ dan panjangnya $3 \mathrm{~m}$, dengan tinggi $2 \mathrm{~m}$. Benih kedelai ditanam dua minggu setelah olah lahan. Sebelum ditanam, benih direndam di dalam larutan Atonik dan Dithane M-45. Benih ditanam dengan jarak tanam $40 \mathrm{~cm} \times 20 \mathrm{~cm}$. Lubang tanam dibuat menggunakan tugal dengan kedalaman $\pm 2 \mathrm{~cm}$, setiap lubang tanam diisi dua benih kedelai. Pemupukan dilakukan saat tanaman berumur $2 \mathrm{mst}$ dengan cara pengocoran pada jarak $5-6 \mathrm{~cm}$ dari lubang tanam. Pupuk $\mathrm{N}, \mathrm{P}$, dan $\mathrm{K}$ diberikan dengan dosis Urea 75 k./ha-1, SP-36 100 kg.ha-1 dan KCl 100 kg.ha-1. Pemeliharan meliputi pengairan secara intensif, pengendalian gulma secara manual pengendalian OPT menggunakan Furadan 3GR dosis 40 gram per petak untuk mengendalikan uret, pengendalian lainnya menggunakan Marshal 25 DS untuk mencegah bibit tanaman kedelai terserang hama lalat bibit (Agrozyma sp.). Marshal 25

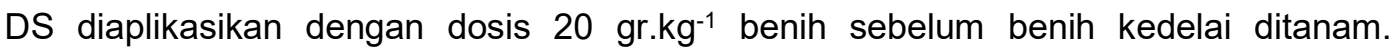
Insektisida Dursban 200 EC dengan dosis 1,5-2 liter.ha-1 untuk mengendalikan hama ulat dan belalang. Insektisida diaplikasikan pada fase pembentukan polong, karena tanaman kedelai rentan terhadap serangan hama penggerek polong (Etiella zinckenella). Panen dilakukan saat tanaman sudah mencapai masak fisiologis yang ditandai dengan warna polong kecoklatan dan kering. Panen dilakukan pada pagi hari dengan cara mengambil seluruh bagian tanaman selanjutnya polong dipetik secara 
manual. Polong yang sudah dipanen kemudian dijemur hingga kering yakni selama 2 hari. Polong yang sudah kering kemudian dipisahkan antara biji dengan kulitnya. Biji bersih kemudian ditimbang dan dikemas berdasarkan label perlakuan lalu dioven. Bobot kering biji dicatat sebagai hasil biji

Parameter pengamatan yang diamati terdiri atas pengamatan lingkungan meliputi intensitas cahaya, suhu udara, kelembaban udara, dan kadar lengas tanah; pengamatan pertumbuhan dan hasil tanaman meliputi tinggi tanaman, jumlah daun, luas daun, bobot kering tanaman, umur mulai muncul bunga, umur mulai terbentuk polong, umur panen, komponen hasil dan hasil kedelai, pengamatan fisiologi tanaman meliputi stomata dan kadar klorofil daun.

Data yang diperoleh dari hasil pengamatan dilakukan analisis varian (ANOVA) dengan taraf kepercayaan $95 \%$. Apabila antar perlakuan menunjukkan adanya beda nyata diuji lanjut dengan Duncan Multiple Range Test (DMRT) dengan taraf kepercayaan $95 \%$. Untuk menentukan tingkat naungan kritis digunakan analisis regresi.

\section{HASIL DAN PEMBAHASAN}

Kondisi lingkungan merupakan salah satu faktor yang mempengaruhi pertumbuhan tanaman. Intensitas cahaya, suhu udara, kelembaban udara, dan kadar lengas tanah berfluktuasi baik pada pagi, siang, maupun sore hari selama penelitian berlangsung. Lahan pasir pantai Samas berada di Desa Srigading, Sanden, Bantul. Jenis tanah Entisol dengan $\mathrm{pH} 7,14$.

Rerata intensitas cahaya pada naungan $50 \%, 25 \%$, dan $0 \%$ pada pagi hari masing-masing adalah 12331 lux, 18455 lux, dan 24635 lux; siang hari adalah 27091 lux, 39532 lux, dan 54049 lux; sedangkan sore hari adalah 10889 lux, 15020 lux, dan 20029 lux. Rerata suhu udara pada naungan $50 \%$, 25\%, dan $0 \%$ pada pagi hari masingmasing adalah $32,4^{\circ} \mathrm{C}, 32,6^{\circ} \mathrm{C}$, dan $34,8^{\circ} \mathrm{C}$; siang hari adalah $34,5^{\circ} \mathrm{C}, 36,0^{\circ} \mathrm{C}$, dan $38,3^{\circ} \mathrm{C}$; sedangkan sore hari adalah $32,3^{\circ} \mathrm{C}, 33,6^{\circ} \mathrm{C}$, dan $35,3^{\circ} \mathrm{C}$. Rerata kelembaban udara pada naungan $50 \%, 25 \%$, dan $0 \%$ masing-masing pada pagi hari adalah $72 \%$, $70 \%$, dan $60 \%$; siang hari adalah $59 \%, 56 \%$, dan $54 \%$; sedangkan sore hari adalah $74 \%$, $73 \%$, dan $70 \%$. 
Tabel 1. Tinggi tanaman (cm) kedelai pada beberapa perlakuan naungan (\%) dan takaran pupuk kandang kambing Etawa (ton.ha ${ }^{-1}$ ) umur 42 hst.

\begin{tabular}{|c|c|c|c|c|}
\hline \multirow{2}{*}{ Takaran pupuk } & \multicolumn{3}{|c|}{ Naungan } & \multirow{2}{*}{ Rerata } \\
\hline & 0 & 25 & 50 & \\
\hline 0 & $31,50 \mathrm{e}$ & 37,50 cde & $45,60 \mathrm{~b}$ & 38,20 \\
\hline 10 & $34,23 \mathrm{de}$ & $40,53 \mathrm{bcd}$ & $56,33 a$ & 43,70 \\
\hline 20 & 36,20 cde & $43,90 \mathrm{bc}$ & $60,90 \mathrm{a}$ & 47,00 \\
\hline Rerata & 33,98 & 40,64 & 54,28 & 42,97 \\
\hline CV (\%) & & $9,43(+)$ & & \\
\hline
\end{tabular}

Keterangan: Dalam suatu kolom, angka diikuti oleh huruf sama menunjukkan tidak berbeda nyata pada uji DMRT $\alpha=5 \%$. Tanda $(+)$ menunjukkan ada interaksi antar perlakuan

Hasil penelitian menunjukkan bahwa terdapat interaksi antara perlakuan naungan dan takaran pupuk kandang kambing Etawa terhadap tinggi tanaman umur 42 hst (Tabel 1). Tinggi tanaman terbaik dihasilkan oleh interaksi perlakuan naungan $50 \%$ dan takaran pupuk kandang kambing etawa 20 ton.ha $^{-1}$ yang tidak berbeda nyata dengan perlakuan naungan 50 \% dan takaran pupuk kandang kambing Etawa 10 ton.ha1. Tanaman kedelai yang tidak diberi naungan pada berbagai takaran pupuk kandang kambing Etawa menghasilkan tinggi tanaman yang nyata lebih rendah dibandingkan perlakuan interaksi perlakuan yang lain meskipun tidak berbeda nyata dengan tanaman kedelai tanpa pupuk pada naungan 25\%. Hal ini terjadi karena takaran pupuk kandang kambing Etawa memiliki sifat lepas lambat (slow release) sehingga unsur hara baru tersedia dan dapat dimanfaatkan oleh tanaman mulai umur 42 hst. Tingkat naungan yang semakin rapat akan menunjukkan tinggi tanaman paling tinggi. Hal tersebut diakibatkan intensitas cahaya yang sampai ke tajuk tanaman semakin rendah sehingga tanaman mengalami etiolasi. Gejala etiolasi terjadi karena tunas apikal lebih aktif tumbuh untuk mencari cahaya agar dapat melakukan fotosintesis dengan baik. Oleh karena itu pertumbuhan organ tananaman menjadi terhambat. Gardner et al. (1991) menyatakan bahwa tanaman yang mendapatkan perlakuan naungan yang lebih rapat menunjukkan pertumbuhan yang lebih cepat karena kerja hormon auksin tidak terhambat. Sedangakan tanaman di tempat terbuka memiliki batang lebih pendek. Hal ini disebabkan intensitas cahaya yang tinggi memacu kerja hormon auksin lebih aktif. Hormon auksin berperan dalam penjagaan sel tanaman.

Tabel 2 menunjukkan bahwa tidak terdapat interaksi antar perlakuan pada variabel jumlah daun. Hasil penelitian menunjukkan bahwa penambahan pupuk kandang kambing mampu meningkatkan jumlah daun tanaman kedelai di Lahan Pasir Pantai pada umur 63 hst, dimana takaran pupuk 20 ton. ha-1 menghasilkan jumlah daun tertinggi dibandingkan takaran 10 ton.ha- $^{-1}$ dan kontrol. Hal ini dikarenakan penambahan pupuk 
Ningrum et al. / Vegetalika. 2020. 9(2): 374-387

20 ton.ha-1 $^{-1}$ dapat meningkatkan kesuburan tanah sehingga tanaman dapat mempercepat pertumbuhan vegetatif terutama pertumbuhan daun menjadi lebih banyak.

Tabel 2. Jumlah daun tanaman kedelai pada perlakuan naungan (\%) dan takaran pupuk kandang kambing Etawa (ton.ha- ${ }^{-1}$ )

\begin{tabular}{cccccccc}
\hline \multirow{2}{*}{ Perlakuan } & \multicolumn{7}{c}{ Umur tanaman (hst) } \\
\cline { 2 - 8 } & 21 & 28 & 35 & 42 & 49 & 56 & 63 \\
\hline Naungan & & & & & & & \\
0 & $6,30 \mathrm{a}$ & $9,63 \mathrm{a}$ & $11,04 \mathrm{a}$ & $19,63 \mathrm{a}$ & $19,30 \mathrm{a}$ & $18,07 \mathrm{a}$ & $14,81 \mathrm{a}$ \\
25 & $6,37 \mathrm{a}$ & $9,63 \mathrm{a}$ & $11,34 \mathrm{a}$ & $20,67 \mathrm{a}$ & $17,93 \mathrm{a}$ & $19,18 \mathrm{a}$ & $13,04 \mathrm{a}$ \\
50 & $5,93 \mathrm{a}$ & $9,56 \mathrm{a}$ & $11,11 \mathrm{a}$ & $19,04 \mathrm{a}$ & $19,22 \mathrm{a}$ & $17,07 \mathrm{a}$ & $13,48 \mathrm{a}$ \\
Takaran pupuk & & & & & & & \\
0 & $5,85 \mathrm{p}$ & $9,56 \mathrm{p}$ & $11,04 \mathrm{p}$ & $18,29 \mathrm{p}$ & $17,77 \mathrm{p}$ & $17,41 \mathrm{p}$ & $12,22 \mathrm{q}$ \\
10 & $6,52 \mathrm{p}$ & $9,19 \mathrm{p}$ & $10,96 \mathrm{p}$ & $20,89 \mathrm{p}$ & $19,11 \mathrm{p}$ & $17,63 \mathrm{p}$ & $12,89 \mathrm{q}$ \\
20 & $6,22 \mathrm{p}$ & $10,07 \mathrm{p}$ & $11,48 \mathrm{p}$ & $20,15 \mathrm{p}$ & $19,89 \mathrm{p}$ & $19,92 \mathrm{p}$ & $16,22 \mathrm{p}$ \\
\hline CV $(\%)$ & 12,16 & 9,16 & 13,84 & 18,66 & 21,51 & 19,74 & 21,30 \\
\hline
\end{tabular}

Keterangan: Dalam suatu kolom, angka diikuti oleh huruf sama menunjukkan tidak berbeda nyata pada uji DMRT $\alpha=5 \%$

Perbedaan intensitas cahaya matahari yang diterima oleh tanaman pada berbagai taraf naungan tidak berpengaruh nyata terhadap pertumbuhan jumlah daun pada setiap minggu pengamatan sampai dengan umur 63 hst. Hasil ini sesuai dengan yang dilaporkan oleh Oosting (1958) bahwa jumlah daun tanaman yang ternaungi lebih sedikit karena tanaman lebih tinggi, jarak tiap buku tanaman lebih panjang daripada tanaman tanpa pengaruh naungan.

Hasil penelitian yang ditunjukkan pada Tabel 3 menunjukkan bahwa tidak terdapat interaksi antar perlakuan pada variabel luas daun kedelai. Perlakuan naungan berpengaruh nyata terhadap luas daun tanaman kedelai pada 42 hst. Perlakuan naungan $25 \%$ memiliki daun paling luas dan berbeda nyata dengan perlakuan tanpa naungan meskipun berbeda tidak nyata dengan naungan $50 \%$. Luas daun perlakuan takaran pupuk kandang kambing Etawa tidak berbeda nyata pada umur tanaman 42 hst dan 63 hst. Perlakuan takaran pupuk kandang kambing Etawa memberikan pengaruh secara nyata pada umur 21 hst. Perlakuan takaran pupuk kandang kambing Etawa 20 ton.ha-1 memiliki luas daun paling luas $\left(436,01 \mathrm{~cm}^{2}\right)$ dan berbeda nyata dengan perlakuan kontrol $\left(295,68 \mathrm{~cm}^{2}\right)$ meskipun tidak berbeda nyata dengan perlakuan takaran pupuk kandang kambing 10 ton.ha-1 $\left(349,59 \mathrm{~cm}^{2}\right)$.

Tabel 3 juga menunjukkan bahwa naungan $25 \%$ dan $50 \%$ menghasilkan daun tanaman kedelai yang nyata lebih luas dibandingkan kontrol pada umur 42 hst karena adanya modifikasi morfologi daun, hal tersebut sebagai wujud toleransi tanaman 
terhadap cahaya rendah. Bukti tanaman mentoleransi adanya cahaya rendah yaitu daun lebih luas, warna daun lebih hijau, dan daun lebih tipis.

Tabel 3. Luas daun ( $\mathrm{cm}^{2}$ per 2 tanaman) tanaman kedelai pada perlakuan naungan (\%) dan takaran pupuk kandang kambing Etawa (ton.ha- ${ }^{-1}$ )

\begin{tabular}{cccc}
\hline Perlakuan & \multicolumn{3}{c}{ Umur tanaman (hst) } \\
\cline { 2 - 4 } & 21 & 42 & 63 \\
\hline Naungan & $314,33 \mathrm{a}$ & $2572,60 \mathrm{~b}$ & $597,20 \mathrm{a}$ \\
0 & $390,11 \mathrm{a}$ & $5086,30 \mathrm{a}$ & $755,80 \mathrm{a}$ \\
25 & $376,84 \mathrm{a}$ & $5046,40 \mathrm{a}$ & $1010,50 \mathrm{a}$ \\
50 & & & \\
Takaran pupuk & $295,68 \mathrm{~b}$ & $4177,40 \mathrm{a}$ & $944,40 \mathrm{a}$ \\
0 & $349,59 \mathrm{ab}$ & $4897,00 \mathrm{a}$ & $692,90 \mathrm{a}$ \\
10 & $436,01 \mathrm{a}$ & $3630,90 \mathrm{a}$ & $726,20 \mathrm{a}$ \\
\hline 20 & 34,76 & 36,03 & 38,69 \\
\hline
\end{tabular}

Keterangan: Dalam suatu kolom, angka diikuti oleh huruf sama menunjukkan tidak berbeda nyata pada uji DMRT $\alpha=5 \%$

Tabel 4 menunjukkan bahwa tidak terdapat interaksi antar perlakuan pada variabel jumlah stomata, panjang stomata, lebar stomata dan luas stomata daun kedelai umur 63 hst. Hasil penelitian menunjukkan bahwa aplikasi pupuk kandang sampai dengan takaran 20 ton.ha-1 tidak berpangeruh secara nyata terhadap variabel stomata yang diamati. Hasil penelitian juga menunjukkan bahwa naungan $25 \%$ dan $50 \%$ nyata menurunkan jumlah stomata, daun tanaman kedelai dibandingkan kontrol. Hasil penelitian juga menunjukkan bahwa panjang, lebar dan luas stomata dipengaruhi secara nyata oleh tingkat naungan yang diterima tanaman kedelai, naungan 50\% nyata meningkatkan panjang dan lebar stomata daun tanaman kedelai. Luas stomata daun kedelai paling luas adalah pada perlakuan naungan $50 \%$ yang berbeda nyata dengan perlakuan naungan $25 \%$ dan $0 \%$. Hal ini berkaitan dengan mekanisme penyesuaian stomata terhadap kandungan air tanah yang dipengaruhi oleh kapasitas tanah dalam menyimpan air. Mekanisme penyesuaian stomata terhadap kandungan air tanah yang dipengaruhi oleh kapasitas tanah dalam menyimpan air. Hal ini diduga semakin tinggi kapasitas tanah dalam menyimpan air maka $\mathrm{pH}$ tanah juga semakin tinggi. Lingkungan dengan $\mathrm{pH}$ tanah tinggi lebih baik bagi aktivitas enzim posporilase dalam mengubah amilum menjadi glukosa-1-phospat. Enzim posporilase mengubah amilum yang terdapat di dalam sel penutup stomata. Keadaan tersebut menyebabkan nilai osmotik lebih tinggi pada sel penutup stomata sehingga air akan dapat masuk ke dalam sel penutup stomata melalui sel tetangga. Air yang masuk dan telah mendominasi di dalam sel penutup 
mengakibatkan tekanan turgor pada dinding sel. Sel penutup yang turgor menyebabkan stomata daun membuka (Dwijoseputro, 1978).

Tabel 4. Jumlah stomata (stomata.10000 $\mu \mathrm{m}^{-1}$ ), panjang dan lebar bukaan stomata $(\mu \mathrm{m})$, dan sebaran stomata $(\mathrm{mm})$ daun pada perlakuan naungan (\%) dan takaran pupuk kandang kambing Etawa (ton.ha-1)

\begin{tabular}{ccccc}
\hline \multirow{2}{*}{ Perlakuan } & \multicolumn{4}{c}{ Stomata } \\
\cline { 2 - 5 } & Jumlah & Panjang & Lebar & Luas \\
\hline Naungan & & & \\
0 & $121 \mathrm{a}$ & $45,42 \mathrm{~b}$ & $13,35 \mathrm{~b}$ & $595,14 \mathrm{c}$ \\
25 & $101 \mathrm{~b}$ & $49,11 \mathrm{ab}$ & $20,90 \mathrm{a}$ & $1032,56 \mathrm{~b}$ \\
50 & $101 \mathrm{~b}$ & $50,36 \mathrm{a}$ & $23,53 \mathrm{a}$ & $1177,69 \mathrm{a}$
\end{tabular}

Takaran pupuk

\begin{tabular}{ccccc}
0 & $115 \mathrm{a}$ & $45,27 \mathrm{a}$ & $19,72 \mathrm{a}$ & $893,34 \mathrm{p}$ \\
10 & $104 \mathrm{a}$ & $50,41 \mathrm{a}$ & $18,23 \mathrm{a}$ & $926,02 \mathrm{p}$ \\
20 & $107 \mathrm{a}$ & $48,84 \mathrm{a}$ & $19,76 \mathrm{a}$ & $986,03 \mathrm{p}$ \\
\hline CV $(\%)$ & 12,80 & 10,40 & 13,20 & 18,29 \\
\hline
\end{tabular}

Keterangan: Dalam suatu kolom, angka diikuti oleh huruf sama menunjukkan tidak berbeda nyata pada uji DMRT $\alpha=5 \%$

Tabel 5 menunjukkan bahwa tidak terdapat interaksi antara perlakuan naungan dan takaran pupuk kandang Etawa pada kandungan klorofil daun kedelai. Perlakuan pupuk kandang kambing Etawa tidak berpengaruh nyata terhadap kandungan klorofil a, b maupun nisbah klorofil a/b pada umur 21, 42 dan 63 hst. Akan tetpai pada perlakuan mandiri kadar takaran pupuk kandang kambing Etawa menunjukkan pengaruh yang nyata kadar klorofil a, b dan nisbah a/b daun kedelai pada umur 42 hst, dimana takaran pupuk kandang kambing Etawa 20 ton.ha-1 menghasilkan kadar klorofil a dan b yang nyata lebih tinggi dibandingkan kontrol. Sebaliknya pada nisbah klorofil a/b takaran 20 ton.ha-1 menghasilkan nisbah klorofil a/b nyata lebih rendah dibandingkan perlakuan yang lain. Tanaman kedelai pada umur 42 hst menunjukkan proses fisiologi yang berlangsung lebih aktif dan menunjukkan respon yang berbeda terhadap perlakuan naungan dan takaran pupuk kandang kambing Etawa yang diberikan. Klorofil berperan penting sebagai penyekap energi sinar matahari dan menghasilkan ATP dan NADPH dalam proses fotosintesis. Dalam daun tanaman terdapat dua macam klorofil yakni klorofil a dan klorofil b. Klorofil a berperan sebagai pusat reaksi yang menyerap dan mengubah energi cahaya menjadi energi kimia. Klorofil a merupakan pigmen utama dan jumlahnya lebih banyak yang berperan dalam reaksi terang fotosintesis. Klorofil b dan karotenoid berperan sebagai pigmen pelengkap. Klorofil b berperan dalam reorganisasi 
fotosistem selama adaptasi terhadap intensitas dan kualitas cahaya. Oleh sebab itu penurunan kandungan klorofil $a$ dan $b$ berpengaruh negatif terhadap efisiensi fotosintesis (Van der Mescht et al., 1999). Jumlah klorofil yang lebih banyak pada tanaman ternaungi memiliki fungsi untuk memaksimalkan penyekapan cahaya. Kultivar toleran, pada kondisi ternaungi memiliki kandungan klorofil lebih tinggi dibandingkan dengan kondisi terbuka. Berdasarkan kenyataan tersebut berarti bahwa klorofil merupakan karakter yang berhubungan dengan toleransi naungan (Salisbury dan Ross, 1995).

Tabel 5. Kandungan klorofil a (mg. $\left.\mathrm{g}^{-1}\right)$, klorofil b $\left(\mathrm{mg}^{-\mathrm{g}^{-1}}\right)$, dan nisbah klorofil a/b $\left(\mathrm{mg} \cdot \mathrm{g}^{-1}\right)$ daun tanaman kedelai pada perlakuan naungan (\%) dan takaran pupuk kandang kambing Etawa (ton.ha-1)

\begin{tabular}{cccccccccc}
\hline \multirow{2}{*}{ Perlakuan } & \multicolumn{3}{c}{ Klorofil a } & \multicolumn{4}{c}{ Klorofil b } & \multicolumn{3}{c}{ Klorofil a/b } \\
\cline { 2 - 10 } & 21 & 42 & 63 & 21 & 42 & 63 & 21 & 42 & 63 \\
\hline Naungan & & & & & & & & & \\
0 & $0,31 \mathrm{a}$ & $0,19 \mathrm{~b}$ & $0,20 \mathrm{a}$ & $0,30 \mathrm{a}$ & $0,13 \mathrm{~b}$ & $0,13 \mathrm{a}$ & $1,19 \mathrm{a}$ & $1,50 \mathrm{a}$ & $1,62 \mathrm{a}$ \\
25 & $0,35 \mathrm{a}$ & $0,26 \mathrm{ab}$ & $0,23 \mathrm{a}$ & $0,33 \mathrm{a}$ & $0,20 \mathrm{~b}$ & $0,16 \mathrm{a}$ & $1,07 \mathrm{a}$ & $1,35 \mathrm{a}$ & $1,61 \mathrm{a}$ \\
50 & $0,40 \mathrm{a}$ & $0,35 \mathrm{a}$ & $0,22 \mathrm{a}$ & $0,40 \mathrm{a}$ & $0,34 \mathrm{a}$ & $0,17 \mathrm{a}$ & $1,06 \mathrm{a}$ & $1,08 \mathrm{~b}$ & $1,46 \mathrm{a}$
\end{tabular}

Takaran pupuk

\begin{tabular}{cccccccccc}
0 & $0,33 p$ & $0,25 p$ & $0,21 p$ & $0,31 p$ & $0,23 p$ & $0,15 p$ & $1,13 p$ & $1,13 p$ & $1,29 p$ \\
10 & $0,36 p$ & $0,26 p$ & $0,21 p$ & $0,36 p$ & $0,21 p$ & $0,14 p$ & $1,09 p$ & $1,09 p$ & $1,32 p$ \\
20 & $0,36 p$ & $0,29 p$ & $0,23 p$ & $0,35 p$ & $0,23 p$ & $0,18 p$ & $1,11 p$ & $1,11 p$ & $1,30 p$ \\
\hline CV $(\%)$ & 26,01 & 20,24 & 40,15 & 25,53 & 26,86 & 23,95 & 23,91 & 10,19 & 19,01 \\
\hline
\end{tabular}

Keterangan: Dalam suatu kolom, angka diikuti oleh huruf sama menunjukkan tidak berbeda nyata pada uji DMRT $\alpha=5 \%$

Hasil penelitian menunjukkan bahwa tidak terdapat interaksi antar perlakuan pada variabel pengamatan umur mulai berbunga, umur mulai terbentuk polong dan umur panen (Tabel 6). Naungan berpengaruh nyata terhadap umur mulai berbunga, umur mulai terbentuk polong dan umur panen kedelai. Umur mulai berbunga terjadi lebih cepat pada naungan $50 \%$ diabndingkan perlakuan naungan $25 \%$ maupun kontrol. Tanaman yang tumbuh pada perlakuan tanpa naungan menunjukkan waktu berbunga lebih lama yaitu 30 hst. Pada dasarnya, umur berbunga tanaman kedelah adalah 33 hst sehingga hal ini menunjukkan umur berbunga dipercepat 7 hari untuk naungan 25\%, 9 hari naungan $50 \%$, dan 3 hari untuk tanpa nuangan. 
Ningrum et al. / Vegetalika. 2020. 9(2): 374-387

Tabel 6. Umur mulai berbunga (hst), umur mulai terbentuk polong (hst), dan umur panen (hst)

\begin{tabular}{cccc}
\hline Perlakuan & $\begin{array}{c}\text { Umur mulai muncul } \\
\text { bunga }\end{array}$ & $\begin{array}{c}\text { Umur mulai terbentuk } \\
\text { polong }\end{array}$ & Umur panen \\
\hline 0 & $30 \mathrm{c}$ & $44 \mathrm{c}$ & $83 \mathrm{c}$ \\
25 & $26 \mathrm{~b}$ & $38 \mathrm{~b}$ & $74 \mathrm{~b}$ \\
50 & $24 \mathrm{a}$ & $35 \mathrm{a}$ & $71 \mathrm{a}$ \\
Takaran pupuk & & & \\
0 & $26 \mathrm{p}$ & $39 \mathrm{p}$ & $76 \mathrm{p}$ \\
10 & $26 \mathrm{p}$ & $39 \mathrm{p}$ & $76 \mathrm{p}$ \\
20 & $25 \mathrm{p}$ & $39 \mathrm{p}$ & $76 \mathrm{p}$ \\
\hline CV (\%) & 3,99 & 0,49 & 0,25 \\
\hline
\end{tabular}

Keterangan: Dalam suatu kolom, angka diikuti oleh huruf sama menunjukkan tidak berbeda nyata pada uji DMRT $\alpha=5 \%$

Pembungaan tanaman kedelai pada naungan $50 \%$ terjadi lebih awal. Umur muncul bunga suatu tanaman berkaitan dengan pertumbuhan tinggi tanaman dan jumlah daun. Pada naungan 50\% tanaman kedelai menunjukkan tinggi tanaman tertinggi dibandingkan dengan perlakuan naungan 25\% dan kontrol. Umur mulai berbunga pada tanaman kedelai dipengaruhi oleh panjang hari dan suhu lingkungan (Baharsjah et al., (1985) dalam Suyamto dan Musalamah, 2010). Pembungaan merupakan faktor pertumbuhan yang cukup peka terhadap perubahan suhu (Akter, et al., 2013). Peningkatan suhu udara terjadi pada siang hari pukul 13.00 WIB. Suhu udara dan intensitas cahaya dapat mempengaruhi proses respirasi. Tanaman yang tumbuh dibawah naungan proses respirasi dan fotosintesis melambat, fotosintat yang dihasilkan jauh lebih rendah daripada tanaman di tempat terbuka. Hal tersebut yang menyebabkan pembungaan terjadi lebih awal. Semakin awal tanaman memasuki fase generatif maka pembentukan polong juga terjadi lebih awal (Hasnah, 2003).

Umur mulai terbentuk polong kedelai pada tanaman dibawah naungan 50\% tergolong lebih cepat. Tabel 6 menunjukkan bahwa naungan memberikan hasil yang berbeda nyata terhadap umur tebentuk polong. Naungan $50 \%$ mampu mempercepat umur pemunculan polong secara signifikan. Tanaman kedelai pada perlakuan naungan $50 \%$ memiliki umur muncul polong paling pendek yakni 35 hst dan berbeda nyata dengan perlakuan naungan $25 \%$ yakni 38 hst dan $0 \%$ yakni 44 hst. Hal ini dikarenakan perlakuan naungan dapat mempercepat umur mulai terbentuk polong tanaman kedelai sehingga pemunculan polong menjdai lebih awal daripada tanaman kedelai pada tempat terbuka. Hal tersebut erat kaitannya dengan umur mulai berbunga tanaman kedelai pada perlakuan naungan. Semakin cepat umur muncul bunga maka semakin cepat pula proses pembentukan polong. 
Tabel 6 juga menunjukkan bahwa umur panen kedelai pada naungan 50\% memiliki umur panen yang paling cepat yakni 71 hst dibandingkan dengan perlakuan naungan $25 \%$ dan $0 \%$. Hal ini disebabkan oleh umur berbunga dan umur pembentukan polong yang terjadi lebih awal. Hasil penelitian ini sesuai dengan penjelasan yang menyatakan bahwa pemberian naungan dapat mempercepat umur masak. Perlakuan naungan 25\% umur masak rata-rata dipercepat sekitar 3 hari, naungan 50\% dipercepat 6 hari, sedangkan naungan $0 \%$ diperlambat 6 hari. Pada perlakuan naungan $0 \%$ (tanpa naungan) memiliki umur panen paling lama yakni $83 \mathrm{hst}$.

Hasil penelitian yang ditunjukkan pada Tabel 7 menunjukkan bahwa tidak terdapat interaksi antar perlakuan pada variabel komponen hasil dan hasil panen tanaman kedelai. Jumlah polong tiap petak produksi, bobot seratus biji, dan hasil biji pada perlakuan naungan tidak berbeda nyata. Jumlah polong hampa dan berisi berbeda nyata baik pada perlakuan naungan. Takaran pupuk kandang kambing Etawa berpengaruh nyata terhadap variabel komponen hasil dan hasil kedelai kecuali pada variabel bobot 100 biji. Takaran pupuk kandang kambing Etawa sampai dengan 20 ton.ha ${ }^{-1}$ mampu meningkatkan secara nyata hasil biji kedelai dibandingkan kontrol.

Tabel 7. Komponen hasil dan hasil tanaman kedelai pada perlakuan naungan (\%) dan takaran pupuk kandang kambing Etawa (ton.ha-1)

\begin{tabular}{|c|c|c|c|c|c|}
\hline Perlakuan & $\begin{array}{c}\text { Jumlah Polong } \\
\text { Per Petak } \\
\text { produksi }\end{array}$ & $\begin{array}{l}\text { Jumlah } \\
\text { Polong } \\
\text { Hampa }\end{array}$ & $\begin{array}{l}\text { Jumlah } \\
\text { Polong Isi }\end{array}$ & $\begin{array}{c}\text { Bobot } \\
\text { Seratus Biji }\end{array}$ & $\begin{array}{c}\text { Hasil } \\
\text { (ton/ha) }\end{array}$ \\
\hline 0 & $330 \mathrm{a}$ & $19 \mathrm{a}$ & $311 \mathrm{~b}$ & 13,68 a & $0,88 \mathrm{a}$ \\
\hline 25 & $413 a$ & $22 b$ & 391 a & $15,47 \mathrm{a}$ & $1,19 \mathrm{a}$ \\
\hline 50 & $399 a$ & $24 a b$ & $375 a b$ & $14,75 \mathrm{a}$ & $1,03 \mathrm{a}$ \\
\hline \multicolumn{6}{|l|}{ Takaran pupuk } \\
\hline 0 & $298 q$ & $19 p$ & $279 q$ & $13,48 p$ & $0,80 \mathrm{q}$ \\
\hline 10 & $425 p$ & $20 p q$ & $405 p$ & $15,56 p$ & $1,17 p$ \\
\hline 20 & $419 p$ & $26 q$ & 393 pq & $14,85 p$ & $1,13 p$ \\
\hline $\mathrm{CV}(\%)$ & 28,02 & 25,25 & 27,19 & 15,59 & 25,96 \\
\hline
\end{tabular}

Keterangan: Dalam suatu kolom, angka diikuti oleh huruf sama menunjukkan tidak berbeda nyata pada uji DMRT $\alpha=5 \%$

Jumlah polong dengan perlakuan naungan 25\% memiliki jumlah polong terbanyak sebesar 413 , diikuti oleh perlakuan naungan $50 \%$ yakni sebesar 399 , dan tanpa naungan sebesar 330 (Tabel 7). Hal ini dikarenakan kedelai melalui teknologi pemuliaan tanaman telah dilakukan perbaikan sifat genetiknya yakni toleran terhadap naungan sampai $50 \%$ sehingga produktivitas tanaman kedelai terbanyak adalah pada perlakuan taraf naungan $50 \%$ meskipun tidak berbeda nyata dengan perlakuan naungan taraf $25 \%$ dan tanpa naungan. 
Tabel 7 juga menunjukkan bahwa jumlah polong perlakuan takaran pupuk 10 ton.ha-1 memiliki jumlah polong paling banyak yakni 425 yang tidak berbeda nyata dengan takaran 20 ton.ha-1 yaitu sejumlah 419 dan berpengaruh secara signifikan dengan kontrol yaitu sejumlah 298. Hal ini berarti penambahan pupuk kandang kambing Etawa mampu memperbaiki tekstur tanah, struktur tanah, dan kesuburan tanah sehingga unsur hara dalam tanah dapat lebih banyak tersedia bagi tanaman. Hal ini diduga proses fotosintesis tanaman tidak terhambat oleh adanya naungan sehingga fotosintat yang dialokasikan untuk pembentukan polong lebih banyak. Jumlah polong tiap petak produksi tidak dipengaruhi oleh perlakuan naungan namun dipengaruhi oleh takaran pupuk kandang kambing Etawa.

Jumlah polong hampa paling banyak terjadi pada tanaman kedelai yang diberi perlakuan naungan $50 \%$, sedangkan jumlah polong berisi paling banyak pada naungan $25 \%$. Tingkat naungan yang semakin tinggi mengakibatkan semakin banyak jumlah polong hampa yang terbentuk pada tanaman kedelai. Hal ini terkait dengan distribusi cahaya matahari yang dapat dipanen oleh daun tanaman. Semakin tinggi taraf naungan semakin rendah cahaya matahari yang sampai ke tajuk tanaman, sehingga proses fotosintesis terhambat. Fotosintesis terhambat mengakibatkan asimilat yang dihasilkan lebih sedikit sedangkan organ tanaman yang membutuhkan karbohidrat tidak hanya biji. Organ tanaman yakni akar, batang, dan daun juga masih membutuhkan distribusi asimilat meskipun hanya sedikit. Asimilat tersebut digunakan untuk mendukung aktivitas metabolisme lainnya.

Bobot 100 biji dengan perlakuan naungan dan takaran pupuk kandang kambing Etawa tidak lebih rendah dari bobot 100 biji pada deskripsi kultivar. Hal ini menunjukkan bahwa kedelai sangat berpotensi untuk dikembangkan sebagai tanaman sela berkanopi dan di bawah tegakan pohon hutan. Hasil penelitian menunjukkan bahwa naungan $50 \%$ tidak menurunkan bobot 100 biji pada kultivar yang diuji. Perlakuan tanpa naungan dapat menurunkan bobot 100 biji kedelai. Bobot paling ringan terdapat pada perlakuan kontrol 


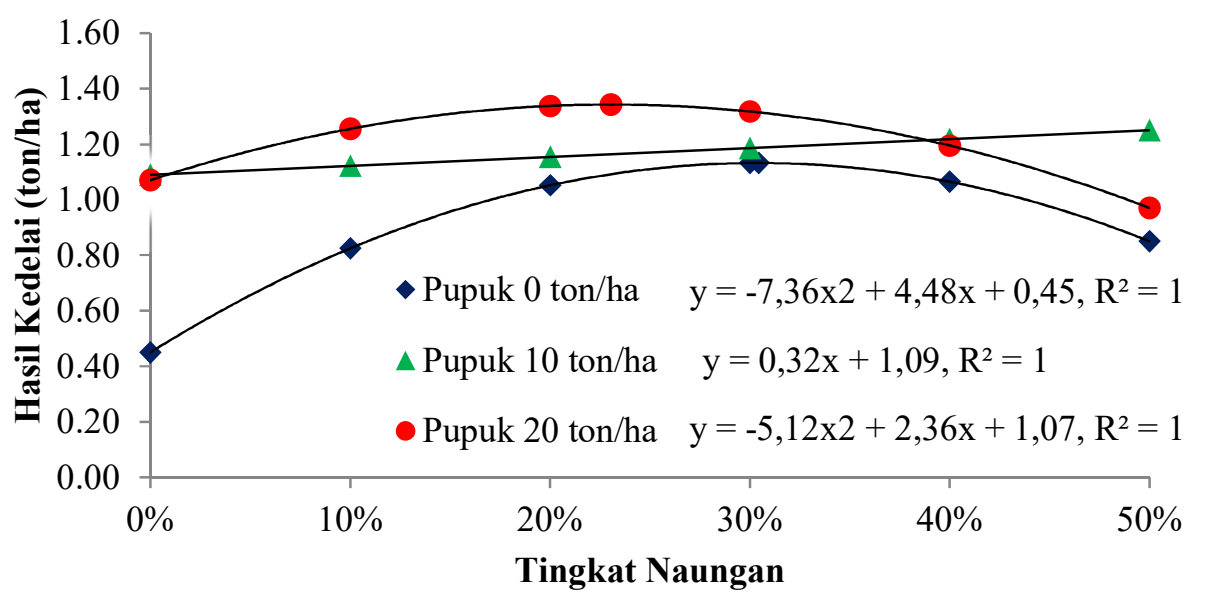

Gambar 1. Hubungan antara intensitas naungan dan hasil biji kedelai

Mengacu pada Gambar 1, hasil biji kedelai perlakuan takaran pupuk 20 ton.ha-1 terjadi titik kritis pada naungan $59,25 \%$ dan kontrol (tanpa naungan) pada $58,16 \%$. Hasil biji menurun seiring dengan meningkanya taraf naungan, sedangkan pada takaran pupuk 10 ton.ha-1 hasil biji cenderung linier sehigga belum nampak titik kritis terhadap naungan. Hubungan antara hasil biji kedelai dengan naungan pada takaran pupuk kandang kambing Etawa 20 ton.ha-1 memiliki kecenderungan negatif dengan persamaan $Y=-5,121 x^{2}+2,36+1,07$. Hubungan antara hasil biji kedelai dengan naungan pada takaran pupuk 10 ton.ha-1 memiliki kecenderungan positif dengan persamaan $Y=0,32$ $+1,09 R^{2}=1$, sedangkan untuk tanpa pupuk $Y=-7,36 x^{2}+4,48+0,45, R^{2}=1$. Nilai $R^{2}$ = 1 menunjukkan bahwa $100 \%$ hasil biji kedelai dipengaruhi oleh naungan.

\section{KESIMPULAN}

1. Tingkat naungan kritis hasil biji kedelai terjadi pada naungan $59,25 \%$ pada takaran pupuk kandang kambing Etawa 20 ton.ha-1 dan naungan $58,16 \%$ pada perlakuan tanpa pemupukan (kontrol).

2. Perlakuan taraf naungan $25 \%$ menunjukkan pertumbuhan dan hasil kedelai terbaik.

3. Takaran pupuk kandang kambing Etawa 10 ton.ha-1 menghasilkan pertumbuhan dan hasil kedelai terbaik dengan pupuk kandang kambing Etawa 10 ton.ha-1.

\section{DAFTAR PUSTAKA}

Adisarwanto, T. \& R. Wudianto. 1999. Meningkatkan Hasil Panen Kedelai di Lahan Sawah-Kering-Pasang Surut. Penebar Swadaya. Jakarta.

Akter, R., M.A. Samad., F. Zaman, dan M.S. Islam. 2013. Effect of weeding on the growth, yield and yield contributing character of mungbean (Vigna radiata L.). J. Bangladesh Agril. Univ 11(1): 53-60. 
Baharsjah, J.S., D. Suardi, dan I. Las. 1985. Hubungan iklim dengan pertumbuhan kedelai. Dalam S. Somaatmadja, M. Ismunadji, Sumarno, M. Syam, S.O. Manurung, dan Yuswadi (eds.) Kedelai. Pusat Penelitian dan Pengembangan Tanaman Pangan. hlm. 87-102.

Dwijoseputro. 1996. Pengantar Fisiologi Tumbuhan. Gramedia. Jakarta. 231 hal

Gardner, F. P., R. B. Pearce, dan R. L. Mitchell. 1991. Physiology of Crop Plants (diterjemahkan dari: Fisiologi Tanaman Budidaya, penerjemah: Herawati Susilo). Penerbit Universitas Indonesia. Jakarta. 428 hal.

Hasnah. 2003. Pengaruh naungan terhadap pertumbuhan kedelai dan kacang tanah. $J$. Agromet 8(1): 21-40.

Oosting, H.J. 1958. Study of Plant Comunities. D.J. Chivers (Ed.). Plenum Press. New York.

Rahayu, T.B., B.H. Simanjuntak, dan Suprihati. 2014. Pemberian kotoran ambing terhadap pertumbuhan dan hasil wortel (Daucus carota) dan bawang daun (Allium fistulosum L.) dengan budidaya tumpangsari. Agric. (1): $52-60$.

Salisbury, F.B. dan C. W. Ross. 1995. Fisiologi Tumbuhan Jilid 3 edisi ke 4. (Terjemahan Bahasa Inggris). ITB. Bandung. 343 hal.

Sunghening, W., Tohari, dan D. Shiddieq. 2012. Pengaruh mulsa organik terhadap pertumbuhan dan hasil tiga varietas kacang hijau (Vigna radiata (L.) Wilczek) di lahan pasir Pantai Bugel, Kulon Progo. Vegetalika 4:67-79. <http://jurnal.ugm.ac.id/jbp/article/view/1519/pdf_29>. Diakses 26 Maret 2016.

Suyamto dan Musalama. 2010. Kemampuan Berbunga, Tingkat Keguguran Bunga, dan Potensi Hasil Beberapa Varietas Kedelai. Buletin Plasma Nutfah Vol 16 (1): 3843.

Van der Mescht, A., J. A. de Ronde, F.T. Rossouw. 1999. Chlorophyll Fluorescence and Chlorophyll Content as A Measure of Drought Tolerance in Potato. South African Journal of Science 95:407-412. 